\title{
A Comparative Analysis of The Conceptions of Muhammad Naquib Al-Attas and Ismail Raji Al-Faruqi In Islamization of Knowledge
}

\author{
Solihah binti Haji Yahya Zikri \\ Academy of Contemporary Islamic Studies (ACIS) \\ Universiti Teknologi MARA Perlis \\ o26oo, Arau, Perlis Indera Kayangan \\ Tel: +6o12-2503242 Emel: solihah86@perlis.uitm.edu.my
}

\begin{abstract}
Abstrak Masalah Islamisasi pengetahuan kontemporer telah banyak didiskusikan dan diperdebatkan di kalangan intelektual muslim. Dua dari Intelektual Muslim yang paling banyak melakukan usaha Islamisasi tersebut adalah al-Attas dan al-Faruqi. Mereka banyak menelurkan konsep tentang permasalahan umat dan Islamisasi pengetahuan sebagai sebuah solusi epistimologi dan sosiopolitik. Penelitian ini bertujuan untuk menguji, membandingkan dan menganalisis pemikiran-pemikiran kedua tokoh tersebut. Pemikiran yang diteliti dalam penelitian ini mencakup ragam interpretasi konsep islamisasi pengetahuan, definisi dari konsep tersebut, kerangka kerja filosofis, dan metodologi yang digunakan untuk mencapai tujuan islamisasi tersebut. Penelitian ini ditujukan
\end{abstract}


18-36 | Solihah binti Haji Yahya Zikri

untuk memahami persamaan dan perbedaan serta kekuatan dan kelemahan dari konsep, kerangka kerja dan metodologi yang digunakan kedua tokoh tersebut. Penelitian ini juga menggali kemungkinan rekonsiliasi dari pemikiran kedua tokoh tersebut dengan harapan dapat dapat meningkatkan konsep islamisasi pengetahuan di masa yang akan datang.

Kata Kunci: Islamisasi Ilmu Pengetahuan, Muhammad Naquib AlAttas, Ismail Raji Al-Faruqi

\begin{abstract}
There has been a lot of discussion and debate on the issues of Islamization of Contemporary Knowledge among Muslim intellectuals. Two Muslim thinkers namely al-Attas and al-Faruqi were foremost in the attempt to conceptualize the problem of the Muslim Ummah and the issue of Islamization of knowledge as an epistemological and socio-political solution. This article aims to examine, compare and analyze the ideas of both scholars with respect to the various interpretations of the concept of Islamization of knowledge their definition of the concept, their philosophical framework, and their methodology for achieving the goals of Islamization. It aims at understanding the similarities and differences and the strengths and weaknesses of their conceptions, philosophical framework and methodology. This paper also explores the possibility of reconciliation between their ideas in the hope of further advancing the cause of Islamization of knowledge.
\end{abstract}

Keywords: Islamization of Knowledge, Muhammad Naquib AlAttas, Ismail Raji Al-Faruqi

\title{
Introduction
}

"Iqra", to read, the opening revelation received by our beloved Prophet Muhammad (pbuh) signifies the importance of knowledge in human life. No civilization in human history achieves its glorious without knowledge. Hence, no doubt the malaise of the Ummahis due to the problem in our education. Due to this situation, contemporary Muslim scholars urge for Islamization of Knowledge which eventually became a mission of Muslim Ummah. 
Solihah binti Haji Yahya Zikri: A Comparative Analysis | 19-36

Many Muslim scholars concerned with the plight of the ummah have been deeply involved with the concept of Islamization of knowledge which gained momentum in the 8 os, as a result of the global consciousness for the "resurgence of Islam" in the 7os and the momentous gathering of prominent scholars in the First World Conference on Muslim Education in Makkah in 1977.

The traditional Muslim scholars contend that all knowledge is from Allah (SWT) and is therefore already Islamized. Hence, there is no need to re-Islamize knowledge but for a different reason. They felt that the modern scientific knowledge is universal and culturally neutral and as such, it cannot be infused with the value system of any particular culture. For instance, Hoodbhoy and Abdus Salam totally reject the concept of Islamic sciences.

The secularist-modernist's view of the neutrality of science were debated and rebutted by contemporary Muslim scientists. Sardar, a physicist, concurs with this view and argues that by divorcing ethics and morality from its epistemology, Western civilization has produced a body of knowledge that does not concern itself with the Islamic concerns of trusteeship of man, sacredness of nature, social justice, public interest and seeking the pleasure of Allah (SWT). He asserts further that this body of knowledge and its associated disciplines promote the interest and well being of Western civilization.' Their view was shared by Nasr, an eminent historian of science who contends that "Muslims must seek to create their own science by incorporating what is positive in modern science into a world-view where God reigns supreme...."

Several attempts have been made during the last decade to translate the concept of Islamization of knowledge into concrete forms such as the publication of monographs and textbooks, and in the establishment of institutions which offer related academic programmers to further the cause. Undoubtedly, two major scholars were in the forefront in this effort,

${ }^{1}$ ZiauddinSardar, Islamic Futures: The Shape of Ideas to Come (Kuala Lumpur: Pelanduk Publication), 1988.

2 Seyyed Hussein Nasr, "Islam and the Problem of Modern Science," Aligarh Journal of Islamic Thought 1 (1988): 20. 
20-36 | Solihah binti Haji Yahya Zikri

namely S.M.Naquib al-Attas and the late IsmailRaji al-Faruqi. Both scholars are taken to be discussed in this essay. The models can be traced through their works i.e. Islam and Secularism and Islamization of Knowledge: General Principle and Work Plan. Two institutions have been established to fulfill this mission i.e. The International Institute of Islamic Thought and Civilization (ISTAC) in Kuala Lumpur in 1987 and The International Institute of Islamic Thought (IIIT) in Herndon, Virginia in 1981. Both scholars have a significant number of followers who have further expanded their efforts. Al-Faruqi and his fellow scholars played a very significant role in mobilizing the Muslim intelligentsia, and in disseminating and popularizing the concept of Islamization of modern knowledge around the world. ${ }^{3}$

It is the aim of this essay to examine, compare and analyze the ideas of both these scholars, hoping that it would lead to an understanding and tolerance among their adherents and interested scholars. The possibility of reconciliation will also be explored. In this manner it is hoped that the effort in Islamization of contemporary knowledge would be further advanced. This paper has four parts. The first one represents on what the scholars mean by Islamization of Knowledge. The second part will cover on the methods proposed by the scholars toward Islamization. Third part is "Discussion" which examines the similarities, differences and some critiques on the models. The last one is "Conclusion".

\section{1: THE CONCEPT OF “ISLAMIZATION OF KNOWLEDGE”}

The "Islamization of knowledge" movement has awakened the ummahfrom their comfortable slumber. Had the term "Islamization" not been used, it would not have drawn the attention of many concerned Muslim and non-Muslim scholars and activists. Muslims had to free themselves from this subjugation through an "epistemological revolution," which later came to be known as the Islamization of contemporary knowledge. Thus, this concept is not merely a slogan, a catchword, a symbol or an empty rhetoric without any significance. It bears a deep meaning especially to those who thought and conceptualized it.

3 Muhammad Shafiq, Growth of Islamic Thought in North America: Focus onIsmailRaji al-Faruqi(Brentwood, Md: Amana Publications, 1984), 31. 
An overview of the works of these leading scholars reveals that they employed more specific phrase related to the concept. Al-Attas for instance, consistently emphasizes and uses the phrase "Islamization of contemporary knowledge" ${ }^{4}$ or the "Islamization of present-day knowledge"5 rather than just "Islamization of knowledge". Even al-Faruqi ${ }^{6}$ also used the phrase of "Islamization of modern knowledge" for his project although later, he tended to use the phrase "Islamization of disciplines." Therefore, whenever both of them employ the phrase "Islamization of knowledge" it actually refers to the "Islamization of contemporary or present-day knowledge." In other words it refers to knowledge based on Western secular worldview; knowledge as conceived and disseminated throughout the world by Western civilization. However, one can be misled by the title ofal-Faruqi's work Islamization of Knowledge: General Principles and Work plan into applying the phrase too broadly to include all kinds of knowledge and not just modern knowledge.

Al-Attas disagrees with the commonly used Arabic phrase aslamah or Islamiyatulma'rifah because he argues ma'rifah is a priori knowledge (already there or innate and independent of experience), and it does not need to be Islamized. He prefers to use the Arabic phrase aslamat 'ulüm al-mu'āșirah or Islamīyatul 'ulüm al-mu'așirah. But one may wish to argue that in the Muslim tradition al-mu'așirah refers to secular knowledge whereas al-ilm refers to religious knowledge. In these sense the former translation is correct because the knowledge that needs to be Islamized

4 S.M.N. Al-Attas, Islam and Secularism 2d ed. (Kuala Lumpur: ISTAC, 1993), preface. He also reiterates this term several times in his weekly Saturday Night Lectures at ISTAC, for example the lecture held in March, 22, 1997, entitled "The Critique of Modernist Thought: The Case of Fazlur Rahman."

5 Al-Attas, Islam and Secularism, 155-156.

6 The closest meaning of the phrase used by both of them is "Islamization of modern Western secular knowledge."

${ }^{7}$ IsmailRaji al-Faruqi, Islamization of Knowledge: General Principles and Work plan (Herndon: IIIT, 1982), 13 \& 48.

8 Take the case of al-Attas for example, in his work The Concept of Education in Islam (Kuala Lumpur: ISTAC, 1991), 43. He uses the phrase "The Islamization of Knowledge." He clearly states in the footnote, referring the readers to his book Islam and Secularism, chapters 1, 11, and V, in which he employed and elaborated the term "Islamization of present-day knowledge." 
is Western secular knowledge and not the religious knowledge. However, such distinction is doubtful because in the Islamic tradition both ilm and ma'rifah are sometimes used interchangeably and the distinction between secular and religious knowledge does not exist. Considering the sensitivity of Muslim community, some scholars prefer to use other terms in place of Islamization such as desecularization, dewesternization, desacralization, resacralization, and holistic integration of knowledge. Although there is some resemblance between these terms, they do not exactly have the same meaning as the term "Islamization." However, they all share the same essence, which is to bring all contemporary knowledge to be consistent with the tawhidic paradigm.

The emergence of the idea of Islamization of contemporary knowledge stems from the basic premise that contemporary knowledge is neither value-free nor universal. Contemporary knowledge has undergone the process or secularization and Westernization which is not only not in harmony but also endangers the Muslim faith. Al-Attas argues that "knowledge is not neutral and can indeed be infused with a nature and content which masquerades as knowledge." ${ }^{9}$

Al-Faruqi further argues that modern knowledge is not universal but is ethnocentric, in particular Eurocentric, and consequently it is not universally applicable. ${ }^{10}$ Since knowledge is not neutral, modern knowledge cannot be applied in tootto the Muslim community which has certain values and beliefs that differ from Western civilization. Contemporary secular Western sources and method of knowledge depend solely on the empirical and rational means. It under values and most often neglects a major means of knowing, the scriptures. Western knowledge is not anchored in transcendental values nor is it related to religious faith. Western sciences are completely secularized. This process of secularization according to Al-Faruqi is due to "their hatred for the Christian Church and the false magisterial it had imposed for itself on all knowledge including that of nature." This incompatibility and incompleteness of Western methods of knowledge led Muslims to seek other alternatives that correspond with the Islamic world-view.

\footnotetext{
9 Al-Attas, Islam and Secularism, 127.

${ }^{10}$ Al-Faruqi, Islamization of Knowledge, 36.

${ }^{11}$ Ibid.
} 
Solihah binti Haji Yahya Zikri: A Comparative Analysis | 23-36

\section{2: AL-ATTAS AND AL-Faruqi's PHILOSOPHICAL FRAMEWORK}

Al-Attas espouses an Islamic metaphysics that is a synthesis of ideas traditionally upheld by Muslim theologians, philosophers and șūfis or ahl al-tasawwuf.' In his metaphysics, the reality and concept of God forms the major thrust of the Islamic world-view and this has deep implications for the concept of knowledge and the concept, contents and methods of Islamic education. ${ }^{13} \mathrm{He}$ asserts that "the knowledge about God is not merely propositional or cognitive, but also more importantly experiential, based on one's intuitive experience and awareness of one's self and of the external world of creation." ${ }^{14} \mathrm{Al}$-Attas enunciates that "all knowledge of reality and of truth and the projection of a true vision of the ultimate nature of things is originally derived through the medium of intuition." ${ }^{15} \mathrm{He}$ affirms that "each metaphysical system, and thus also the world-view it projects, is not the same for every other civilization; it differs from one another in accordance with differences in the interpretation of what is taken to be ultimately true and real. ${ }^{\prime \prime 6}$

According to al-Attas, Islam derives its sources from revelation, confirmed by religion and affirmed by intellectual and intuitive principles. ${ }^{17}$ Al-Attas maintains that knowledge is not totally and purely the product of the human mind and experience but is also based on revealed truth. Thus, Islamization of contemporary knowledge makes sense only within the framework of Islamic metaphysics. Al-Attas maintains that "Islam affirms the possibility of knowledge; that knowledge of the realities of things and their ultimate nature can be established with certainty by means of our external and internal senses and faculties, reason and intuition, and true

${ }^{12}$ Wan Muhammad Nor further elaborates that "The metaphysics of Prof. Al-Attas, in fact all of his articulation about Islam are based on his interpretation of the Qur'an, the Sunnah of the Prophet (SAW) and the teachings of the higher sufis." "An Outline of the Educational Philosophy and Methodology of Al-Attas," Islamization ArastirmalarCilt: 7, Sayi: KisDonemi (1993-94): 35 .

${ }_{3}$ Muhammad Nor "An Outline of the Educational Philosophy," 40.

${ }^{14}$ Ibid.

15 S.M.N. Al-Attas, Prolegomena to the Metaphysics of Islam (Kuala Lumpur: ISTAC, 1995), 177 .

${ }^{16}$ Ibid., ix.

${ }^{17}$ Ibid., 4. 
24-36 | Solihah binti Haji Yahya Zikri

reports of scientific or religious nature, transmitted by their authentic authorities."

Al-Faruqi also affirms that in Islam, nature is neither bad nor evil; rather it is viewed as a creation and a gift. As God's creation it is purposive, perfect and orderly; and as a gift it is created for the benefit of man. The main purpose of creation is to facilitate and assist man to act in good deeds and attain happiness. The orderliness, purposiveness and goodness of nature are the distinctive features of the Islamic view of nature. Although nature has been created for human beings, it should not be abused or exploited and must be used in line with divine purpose,

Moral obligation is impossible without responsibility or reckoning. Judgment or the consummation of responsibility is the necessary condition of moral obligation, or moral imperativeness.

In the introduction of his monograph, al-Faruqistates the necessity of remolding every discipline so as to incorporate the relevance of Islam, along a triple axis which constitutes tawhid. These three axes for Islamization of modern disciplines are:

1. The unity of knowledge, which will abolish the dichotomy between 'aqli[acquired] and naqli[revealed] sciences;

2. The unity of life, which will eradicate the distinction that some sciences are value-involved and some are value-free, thus making all the sciences as value loaded; and

3. The unity of history, which will remove the separation of knowledge into individual and social sciences, forming all disciplines that are the same time humanistic.

\section{3:DEFINITIONOF ISLAMIZATIONOF CONTEMPORARY KNOWLEDGE}

According to Al-Attas, Islamization is "the liberation of man first from magical, mythological, animistic, national-cultural tradition, and then from secular control over his reason and his language". The liberation of his spirit or soul bears direct influence upon man's physical being. It brings about peace and harmony within himself, and also between him and other men and nature. In this sense, man has set his course towards the attainment of his original state, which is in harmony with the state of all being and 
Solihah binti Haji Yahya Zikri: A Comparative Analysis | 25-36 existence (i.e. fitrah). It is also liberation from subservience to his physical demands which are inclined towards the secular and prone to injustice to his true towards self or soul, since man has a tendency towards forgetfulness of his true nature, becoming ignorant of his true purpose and unjust to it. Thus, Islamization is a liberating process. ${ }^{18} \mathrm{Al}$-Attas emphasizes more on secularism as the main cause for problem in our educational system and life as a whole. Secularism divides the educational system.

Al-Attas further explains that Islamization involves firstly the Islamization of language since "language, thought and reason are closely interconnected and are indeed interdependent in projecting to man his world-view or vision of reality. Thus the Islamization of language brings about the Islamization of thought and reason..."This fact is demonstrated by the Holy Qur'an itself when it was first revealed among the Arabs. He argues that the concept of Islamization in general will naturally lead to the Islamization of contemporary knowledge. This is so because thought, reason and language shape the form and kind of knowledge to be generated. Al-Attas explains the Islamization of contemporary knowledge as "the deliverance of knowledge from its interpretations based on secular ideology; and from meanings and expressions of the secular".

Al-Attas clearly identifies and explains the foreign elements and key concepts that should be removed from the body of contemporary Western, secular knowledge that comprises:

1. The concept of dualism which encompasses their vision of reality and truth;

2. The dualism of mind and body; their separation of intellects and ratio, and their stress upon the validity of ratio; their methodological cleavage pertaining to rationalism and empiricism;

3. Their doctrine of humanism; he secular ideology;

4. Their concept of tragedy - mainly in literature.

On the other hand, al-Faruqi explains that Islamization of modern knowledge is recastingKnowledge as Islam relates to it. He believes that to Islamize knowledge is "to redefine, and reorder the data, to rethink

${ }_{18}$ Muhammad Al-Naquib Al-Attas, Islam and Secularism (Delhi, India: New Crescent Publishing Co., 2002), 53. 
26-36 | Solihah binti Haji Yahya Zikri

the reasoning and relating of the data, to reevaluate the conclusions, to reproject the goals and to do so in such a way as to make the disciplines enrich the vision and serve the cause of Islam.

Faruqi sees the problem of education is due to the dichotomy between the modern secular and traditional Islamic systems of education. So, he says, we need to produce and integrated system of education. Thus, he mentions that, what should be done by Islamizers are; "they must integrate the new knowledge into the corpus of the Islamic legacy by eliminating, amending, and adapting its components as the world-view of Islam and its value dictate". He further says; Islamizing knowledge in concrete terms is, to Islamize the disciplines or, better, to produce university level textbooks recasting some twenty disciplines in accordance with Islamic visions." ${ }^{19}$

\section{METHODOLOGY OF ISLAMIZATION OF KNOWLEDGE}

With regards to the method of knowledge, al-Attas's tawhidic method shows unity of all empirical and rational, the deductive and inductive method. He assures that Muslim scholars in the past had utilized several methods in their research. Al-Attas also considers "tafsir and ta'wīlas valid methods of approach to knowledge and scientific methodology respecting our study and interpretation of the world of nature, and its significance in our conception of knowledge and education." According to al-Attas "knowledge includes faith and belief (imān)" and knowledge should be followed by action ('amal) "for there is no useful knowledge without action, and there is no worthwhile action without knowledge." Thus, the ultimate aim of pursuing knowledge in Islam is to be a good man and not a good citizen of a secular state.

For al-Attas, the process of Islamization of contemporary knowledge consists of two major's steps. He reiterates that "knowledge must be imbued with Islamic elements and key concepts after the foreign elements and key concepts have been isolated from its every branch." The infiltration of four elements and key concepts namely secularism, dualism, humanism, and tragedy mostly occurred in the branch of knowledge referred to especially

19 Abdul Hamid A.AbuSulayman, Islamization of Knowledge-General Principles and Work Plan (Herndon: IIIT, 1989), 18-19. 
Solihah binti Haji Yahya Zikri: A Comparative Analysis | 27-36

the human sciences. However, as al-Attas observes these alien concepts also penetrate into the natural, physical and applied sciences that are specifically concerned with the interpretation of facts and formulation of theories.

Al-Attas explicitly indicates the components of the Islamic elements and key concepts that should be infused to the existing body of knowledge after the isolation of the Western elements and key concepts. They are; the concept of religion (Din); man (insan); knowledge ('ilm and ma'rifäh); wisdom (hikmah); justice ('adl); right action ('amal-adab); and the university (kuliyyah-jāmi'ah). ${ }^{20}$ Al-Attas further says that, all the elements should be connected to the concept of tawhìd, sharīah, sirah, sunnah and tarikh. They should also be referred to the elements of tașawwuf, Islamic Philosophy, cosmological doctrines, knowledge of Islamic ethics (akhlāq) and $\bar{a} d \bar{a} b$. Lastly, they should be added with the Arabic knowledge and the Islamic world view in general. ${ }^{21}$

Al-Attas views that; Islamization of contemporary knowledge cannot be done simply by grafting or transplanting secular knowledge into Islamic sciences and principles. This is because the essence of foreign elements will remain in the body of knowledge. Furthermore, the Islamic system is not required to be modernized..$^{22}$ Thus, the total isolation from the alien elements is very important. Then, integration process of the two systems can be implemented.

The aim and objective of Islamization of contemporary knowledge is to protect Muslims from corrupted knowledge that misguides and leads to confusion and skepticism of Muslim minds. It is to produce true knowledge that can develop and mould Muslim minds and bring them to the proper acknowledgement and recognition of God. Knowledge, which is in conformity with its true purpose, fitrah and the Islamic world-view, will bring salvation to man in this world and the hereafter. Islamization of contemporary knowledge will result in peace, goodness and justice and strengthening of the faith.

${ }^{20}$ Syed Muhammad Al-Naquib Al-Attas, Islam and Secularism, 175.

${ }^{21}$ Ibid., 179 .

${ }^{22}$ Mohd.Yusof Hussain (Edt.), Islamization of Human Sciences, 112. 
28-36 | Solihah binti Haji Yahya Zikri

Al-Faruqi's methodology of Islamization of modern knowledge too has been developed and elaborated on the basis of tawhid. For the sake of Islamizing modern knowledge al-Faruqihas laid down fundamental principles of the Islamic world-view that serve as the framework of Islamic thought, methodology and way of life. Al-Faruqi clearly stated the five elements that form the "First Principles of the Islamic Methodology." They are; the Unity of Allah, the Unity of Creation, the Unity of Truth and the Unity of knowledge, the Unity of Life, and the Unity of Humanity. ${ }^{23} \mathrm{Al}$-Faruqi reasons that the Islamic traditional methodology is inadequate to Islamize modern knowledge due to the following shortcomings. First, it confined and restricted the meaning of important terms such as figh, faqīh, ijtihad and mujtahid. For example, the term fighand its derivatives are confined only to the 'ulüm al-sharíah rather than knowledge of Islam as a whole as originally used by the Qur'ān. Second, the traditional method separates wahy(revelation) and 'aql(reason). Third, it separates thought and action. Finally, the traditional method creates cultural and religious dualism that is the bifurcation of the method into two paths, secular and religious. This dichotomy occurred particularly "in the period of decay - because of the estrangement between thought and action - the split into two: the way of the world and the way of God or virtue. These shortcomings could have been avoided if the First Principles were adhered to.

Unlike al-Attas, Al-Faruqigoes a step further in making his ideas concrete. He set up a work plan for the Islamization of modern knowledge which consists of five objectives, as follows:

1. To master the modern disciplines;

2. To master the Islamic legacy;

3. To establish the specific relevance of Islam to each area of modern knowledge;

4. To seek ways for creative synthesis between the legacy and modern knowledge;

5. To launch Islamic thought on the trajectory which leads it to fulfillment of the divine pattern of Allah?

${ }^{23}$ Abdul Hamid A. Abu Sulayman, Islamization of Knowledge-General Principles and Work Plan, 33-53. 
Solihah binti Haji Yahya Zikri: A Comparative Analysis | 29-36

In order to achieve the objectives of the work plan and the aims of Islamization of modern knowledge, Al-Faruqicame out with twelve steps which were presented in 1982 at the Second Conference on Islamic Education at Islamabad, Pakistan. They can be summarized as the following;

1. Mastery of the modern discipline

2. Discipline survey

3. Mastery of Islamic legacy: The Anthology

4. Analysis of Islamic legacy: The Analysis

5. Establishment of the specific relevance of Islam to the disciplines

6. Critical assessment of the modern disciplines

7. Critical assessment of the Islamic legacy

8. Survey of the Ummah's major problems

9. Survey of human problems

10. Creative analyses and syntheses

11. Recasting the disciplines under the framework of Islam

12. Dissemination of Islamized knowledge ${ }^{24}$

The first two steps are to ensure Muslims' understanding and mastery of the disciplines as they have developed in the West. The next two steps are to ensure that modern Muslim scholars who are not too familiar with the Islamic legacy due to the problem of access, will be provided an opportunity to access it from anthologies prepared by traditionally trained Muslim scholars who have access to it. The analysis of Islamic legacy is to better understand the Islamic vision with respect to the historical backgrounds, problems and issues involved. These first four steps should inform the scholars of the contributions of the Islamic legacy and its relevance to the disciplines and their general goals. The sixth step is the major step in the Islamization process where consistency with the First Principles and the five-fold unity are checked before the creative synthesis is reached in step ten.

${ }^{24}$ Mohd. Yusof Hussain, Islamization of Human Sciences (Kuala Lumpur: International Islamic University Malaysia, 2006), 114. The details of the steps can be referred in; Abu Sulayman, Abdul Hamid, Islamization of Knowledge: General Principles and work Plan (USA: International Institute of Islamic Thought, 1997), 58-78. 
30-36 | Solihah binti Haji Yahya Zikri

\section{Discussion}

\section{1: (ANALYSIS OF THE TWO CONCEPTIONS OF ISLAMIZATION OF KNOWLEDGE)}

An analysis of al-Attas and al-Faruqi's philosophical framework shows that they both share the same assumptions about knowledge. Epistemologically, they believe that knowledge is not value-neutral and its attainment is possible. Their aims of knowledge (or true knowledge) are one and the same and their conceptions of knowledge are founded on Islamic metaphysical, ontological, epistemological and axiological principals, which have the concept of tawhid as their pivot. They both share the belief that God is the origin of all knowledge; that knowledge is the basis of faith and good deeds. In fact both of them agree that the root of the ummah'sproblems lies in the educational system and in particular, with the problem of existing knowledge, i.e. Islamization of contemporary or modern secular knowledge. They both share the same fundamental notion of Islamization of modern knowledge which is, that one needs to perform surgery to modern knowledge whereby the bad elements and impurities are eliminated, amended, reinterpreted or adapted to be in accordance with the dictate of the Islamic world-view or values (al-Faruqi's terms) or isolated or removed and then infused with Islamic elements and key concepts (al-Attas terms).

However, there are few fundamental differences between the two scholars in spite of apparent similarities. First, it is quite conspicuous that al-Attas as compared toal-Faruqi has a more elaborate and convincing philosophical framework in which his metaphysical, epistemological and axiological principles are carefully drawn out in many of his works. He has delved deeply on the relationship between the nature of man, knowledge, faith and education. Another area of difference lies in their definition of Islamization of contemporary knowledge. Although the two definitions of al-Attas and al-Faruqibear a close resemblance with one another as articulated above, there is still a slight difference.

In term of defining the concept of Islamization of knowledge, it seems that Al-Attas tend to have more clear explanation than Faruqi. However, 
Faruqi gave great effort on presenting the plan and how to implement Islamization. Thus, his methodology is clearer than Al-Attas.

But, still, Faruqi's methodology need more detail explanation. However, his monograph in 1982 is the first step. So, it is more on "work plan". His model received much criticism from Western and Muslim scholars. Weakness on the methodology is said to be the cause for slow progress. Not many text books for university level were produced. Thus, many scholars made attempts to revise the work plan. The twelve steps of the work plan were reduced to three, i.e. mastery of substantive knowledge, mastery of methodological knowledge and production of university text books or general works. It is also mentioned that the knowledge produced by the procedure can not immediately be considered as "Islamized knowledge". It needs to have a close and critical evaluation by Muslim scholars and community. ${ }^{25}$

Today, internet is a powerful tool for communication. Thus, we must use it effectively and usefully for implementing Islamization of knowledge. Internet cannot be rejected in this effort. In fact, we must use different methods to spread the knowledge. This has been mentioned by Mohd. Yusof Hussain. Although internet is a threat to Islamization process, but, Muslims need to take it as an opportunity to reach the global audience. ${ }^{26}$ Another point that stressed out by Mohd.Yousuf, that can strengthen the models is, Islamization of personality. He says, the Islamizers should have the true Islamic personality and characters. ${ }^{27}$

The idea of Islamization of knowledge came out since 1970s to 1980s, so it is hoped that there is serious effort to implement the Islamization at school level especially in primary and secondary schools. The two models focus more to university level. We need text books for school children. It is more valuable if we can instill the spirit and principles of Islamization to this young generation at early age. The two models are still relevant but, need some additional points and plans to face the new challenges. So, some revision is need from time to time.

\footnotetext{
${ }^{25}$ Mohd.Yusof Hussain, Islamization of Human Sciences, 13.

${ }^{26}$ Ibid. 15 .

${ }^{27}$ Yasien Mohamed, "Islamization of Knowledge: A comparative Analysis of Faruqi and Rahman", 16.
} 
Al-Faruqireveals the shortcomings of both the traditional and modern method and synthesizes the positive aspect of both in order to produce Islamized knowledge. Al-Attas however, would not agree with al-Faruqi'sstep in the work plan which indicates that the latter already regarded the problem to also lie within the Islamic tradition. For al-Attas the problem lies in the Western modern secular knowledge. Therefore there is a dire need to Islamize modern knowledge but not Islamic traditional knowledge because the latter does not suffer from secularization. It has been Islamized, to a certain degree. In other words, al-Faruqi's concept of Islamization of modern knowledge constitutes double movement theory in the sense that it requires reconstruction of both modern and Islamic traditional knowledge. He calls to identify the past Muslim legacy in order to establish its relevance to modern knowledge. Al-Attas does call for an examination of the Islamic legacy not for establishing its relevance to modern knowledge, but rather to scrutinize and verify how far the modern knowledge has diverged or deviated from the tradition.

The difference is also conspicuous between al-Faruqiand al-Attas, regarding the significance of tasawwuf (Sufism) in formulating basic concepts in all branches of knowledge. Al-Faruqilike othersalafiyyah (revivalist) reformists such as Muhammad Ibn 'Abd al-Wahhab, and Abul A'lā Mawdudi, berates tasawwuf and considers that "the spirituality as manifested throughtasawwuf only leads to decay and hence should be regarded as not only as not essential but also harmful. Al-Attas, on the other hand, considered tasawwuf not only significant but necessary for formulation of the theory of knowledge and education. In fact alAttas argues that "...no formulation of a philosophy of education and a philosophy of science along Islamic lines can be developed by ignoring the great contributions of the șufĩ masters on the ultimate nature of reality."

These different views on tasawwuf as a method and source of knowledge hold several implications for the concept of knowledge, education and Islamization of contemporary knowledge and Islamization in general. Al-Faruqi's concept on Islamization of modern knowledge for instance emphasizes more on society or socio-economic and political 
Solihah binti Haji Yahya Zikri: A Comparative Analysis | 33-36

changes. This is evident from his frequent use of the word ummah in his works. In fact, the IIIT has been more dynamic in disseminating the idea of Islamization of Knowledge to the Muslim masses through its regular activities in the form of seminars, conferences and has set up several branches in different parts of the world. Al-Attas' conception of Islamization of contemporary knowledge on the other hand, emphasizes more in the individual rather than society because when he is talking of Islamization of contemporary knowledge he is dealing with individual which will be followed by change in society. ISTAC is serious in its role of Islamizing knowledge and personalities and producing the Islamized scholars as evident from its publications. However there have been critics of some of its academic staff who do not portray the character of an Islamic personality.

In certain aspects, it is evident that both scholars have overly generalized the West as though composing of a particular school of thought, in particular the logical positivist. In fact Western scholars were reexamining their approaches and were gradually undergoing a philosophical transformation in its research methodology after being held captive by the obsession over behaviorism and other offspring's of empiricism in their attempts to understand, explain and predict human behaviors.

\section{Conclusion}

\section{1: (THE POSSIBILITY OF RECONCILIATION)}

This analysis has attempted to show that al-Attas and al-Faruqi, two eminent Muslim scholars, share similar metaphysical principles with tawhid as the foundation of their ideas. They subscribe to similar epistemological and axiological which are grounded to their metaphysics. Apart from minor differences, their concepts and definitions of Islamization of contemporary knowledge bear very close resemblance. The only major fundamental difference between them lies in the process and methodology of Islamization of knowledge itself. Methodological difference is minor 
34-36 | Solihah binti Haji Yahya Zikri

compared to differences in philosophical framework that forms the basis of their paradigm. Therefore, we are optimistic on the possibility of reconciliation and cooperation, assuming that the followers of both parties are able to take into account each other's strengths and weakness, and are able to reach out to each other in honest, intellectual discourses. Al-Faruqi's methodology seems to contain a few logical inconsistencies. For example, his work plan is devoted to Islamizing "discipline" rather than knowledge as he had defined. Further, his attempt to make Islam relevant to modern knowledge does not follow the normal logical order of knowledge as classified by early Muslim scholars such as al-Ghazali, who would place the naqliyyahknowledge higher in the hierarchy than the 'aqliyyah knowledge. Al-Faruqihas incidentally put the cart before the horse. Thus it has received much criticism from other Muslim scholars.

Already AbuSulayman, one of al-Faruqi's team members has provided indispensable clarifications of the concept and significant modifications were made in the second edition of the monograph which was published in 1988. Similarly, Safi, another scholar affiliated to the team has suggested the need to modify al-Faruqi's work plan into something more realistic by reducing the twelve steps to three.

With respect to the different emphasis on society and on the individual given by both scholars, one may attempt to bridge it by taking the middle path that is a balanced or unified approach. Such an approach gives equal emphasis to both individual and societal change. In other words, the emphasis on societal change should not be at the expense of individual change and vice-versa. Similarly with respect to the scientific methodology, both intuition and reason should be accepted as sources and methods of knowledge as the case for experiment and revelation. Thus it implies that reason should not be employed at the expense of revelation and vice-versa, rather they should both be employed in a proper and balanced manner that complement each other. In this way al-Faruqifears of an overemphasis of one at the cost of the other can be avoided.

As a conclusion, it might be possible that al-Faruqiborrowed al-Attas's idea and developed it further based upon his own understanding. Hence, 
Solihah binti Haji Yahya Zikri: A Comparative Analysis | 35-36

the difference with al-Attas who regrets that al-Faruqihas done injustice to his original idea, making it more confusing and "depriving theummah of knowledge of the right direction." Despite this, one has to acknowledge and appreciate the efforts of al-Faruqiand IIIT in raising the awareness of Muslim intellectuals of their epistemological, social and political problems, disseminating this idea and advancing it. Therefore it is essential for Muslim intellectuals to understand fully the concept of Islamization of contemporary knowledge and work together towards its fulfillment. The differences in opinions and approaches within the boundary of Islam are a blessing from Allah (SWT) and should be tolerated and appreciated, as long as the aims are noble and there is complete sincerity among those who attempt to realize those aims. With some difficulties, challenges and different views among scholars, however, nowadays Islamization is not only became the concern of Muslim intellectuals but also people, institutions and governments. We need a lot of effort to achieve the vision and mission of Islamization of Knowledge. All of us should remember that, Islamization of knowledge is a long life commitment and process.

\section{References}

Abdul Hamid A. Abu Sulayman, Islamization of Knowledge-General Principles and Work Plan, International Institute of Islamic Thought, Herndon, 1989 .

Fazlur Rahman, Islam and Modernity: Transformation of an Intellectual Tradition, the University of Chicago Press, Chicago, London, 1982. , "Islamization of Knowledge: A Response:" The American Journal of Islamic Social Sciences 5, 1988.

Ismail Raji al-Faruqi,Islamization of Knowledge: General Principles and Work plan (Herndon: IIIT), 1982.

Mohd. Yusof Hussain (Edt.), Islamization of Human Sciences, Research Centre, International Islamic University Malaysia, Kuala Lumpur, 
36-36 | Solihah binti Haji Yahya Zikri

2006.

Muhammad Shafiq, Growth of Islamic Thought in North America: Focus onIsmail Raji al-Faruqi (Brentwood, Md: Amana Publications, 1984.

Muhammed Abdus Salam, "Foreword, "in Hoodbhoy, Islam and Science.

ParvesHoodbhoy, Islam and Science: Religious Orthodoxy and the Battle for Rationality (London: Zed Books Ltd.), 1991.

S.M.N. Al-Attas, Prolegomena to the Metaphysics of Islam (Kuala Lumpur: ISTAC), 1995 .

Seyyed Hussein Nasr, "Islam and the Problem of Modern Science," Aligarh Journal of Islamic Thought 1, 1988.

Syed Muhammad Al-Naquib Al-Attas, Islam and Secularism, New Crescent Publishing Co., Delhi, India 2002.

Yasien Mohamed, "Islamization of Knowledge: A Comparative Analysis of Faruqi and Rahman", Muslim Education Quarterly, Vol. 11, No. 1, 1993. 